\title{
VASÚTI KUTATÁSOK - AZ EURÓPAI VASÚTI ÁGAZAT VERSENYKÉPESSÉGE
}

\section{RAILWAY RESEARCHES - COMPETITIVENESS OF THE EUROPEAN RAIL INDUSTRY}

\author{
Tokody Dániel \\ Óbudai Egyetem Biztonságtudományi Doktori Iskola, 1081 Budapest, Népszínház \\ utca8,tokody.daniel@mav.hu
}

\begin{abstract}
One of the main remarks of the InnoTrans 2016 was the digitalisation of railway industry and its future challenges. Digitalisation brings a new possibility for the future of the railway industry. The Digital Age and the digital development of transportation also contribute to the competitiveness of European Rail Industry.
\end{abstract}

Keywords: Digital-Age, Railway, ICT, Industry 4.0, roadmap

\section{Összefoglalás}

Az InnoTrans 2016 kiállítás - ami az egyik legnagyobb vasúti ipari fórum - fő motívuma volt a vasúti ipar digitalizálódása és annak jövőbeni kihívásai. A digitalizáció egy új lehetőséget teremt, amely a vasúti ipar jövőjét jelenti. A digitális korszak és a közlekedés digitális fejlődése hozzájárul az az európai vasúti ágazat versenyképességéhez.

Kulcsszavak: digitális kor, vasút, IKT, Ipar 4.0, stratégiai útiterv

\section{Bevezetés}

A digitalizáció egy új lehetőséget teremt, amely a vasúti ipar jövőjét jelenti. A digitális korszak és a közlekedés digitális fejlődése hozzájárul az európai vasúti ágazat versenyképességéhez.

A vasúti rendszer fejlesztésére fordított anyagi források felhasználásának hatékonyságát tovább javítja, ha más szektorokban is pozitív hatásokat tudunk felhasználásukkal gerjeszteni. Ilyen tendencia ma Magyarországon a vasúti fejlesztésekkel, kivitelezésekkel foglalkozó pár tíz darab kis- és középvállalkozás fejlődése. Ezek a cégek bár kis létszámú munkavállalót foglalkoztatnak, de a vasúti fejlesztések mérvadó szereplői azáltal, hogy a vasúti fejlesztésekkel foglalkozó multinacionális cégek magyarországi munkáinak alvállalkozóiként szaktudásukkal segítik a fejlesztések, beruházások megvalósulását.

Holicza szerint 2013-ban a vállalkozások $16,2 \%$ foglalkozott szakmai, tudományos, müszaki tevékenységgel, amelynek csak töredéke lehetet kapcsolatban a vasúti ágazattal. [1]

Jogosan mondhatnánk, hogy az elmúlt évtizedekben a világtrendek hatásának begyürüzése a magyar vasúti ágazatba lassú folyamat volt így van ez a digitalizáció kapcsán is.

Ugyanakkor nem is volt olyan rég egerfarmosi és sztregovai doktor Kandó 
Kálmán és Verebély László világhírü vasútfejlesztői tevékenysége.

Ma viszont Európa 25 országából a Railway Performance Index értékei alapján a magyar vasút közepesen kihasznált rendszere szolgáltatás minőségben és biztonságban a régiós átlagtól elmarad. [2] A mai magyar vasúti infrastruktúra teherbírása sok esetben teljesítőképessége határát súrolja és a végletekig kihasznált rendszer régóta túl van a tervezett élettartartalmon. A teljesítőképesség határán üzemeltetett rendszer a vasútüzem megbízhatóságának korlátját is jelenti. Ennek jó indikátora lehet akár csak a túlzsúfolt vonatok vagy a vasúti teherszállítás szállítási időbizonytalansága.

A gazdasági növekedés kéz a kézben jár az infrastruktúrák fejlettségével, így a közlekedési és a vasúti infrastruktúra fejlettségével is. A gazdasági növekedés gátja lehet a csekély szolgáltatás minőségü vasúti közlekedés. A minőség terén természetesen a biztonság felértékelődése is meghatározó.

A vasúti ágazat szereplői sokat tehetnek a magyar vasút jövőéért és a fenntarthatóbb közlekedési rendszer létrehozásáért. Az intelligens közlekedési rendszerek megvalósítására vasúti területen is folynak kutatások. [3]

\section{Vasúti kutatások a versenyké- pességért}

Európában és hazánkban is a digitális ökoszisztéma létrehozása a fenntarthatóság szempontjából nagy jelentőséggel bír. [4] A digitális technológia átalakítja a közlekedés teljes vertikumát és így a vasúti rendszer struktúráját is. A közlekedési szektor informatizálódása kihatással van például az életminőségre vagy akár az energiahatékonyságra is. [5]

Jóllehet más országokban a vasútra vonatkozó digitális modernizációs tervek már 2060 -ig nyúlnak. Nálunk még mindig a vasúti rendszer teljes strukturális müszaki reformja várat magára.
A vasútal kapcsolatos tudományos kutatások kezdeményezői lehetnek maguk a gyártók, a rendszerintegrátorok, a pályahálózat működtetők, a szolgáltató vasúttársaságok, a hazai és nemzetközi vasúti szervezetek, egyetemek és kutatóintézetek.

UNIFE (The European Rail Industry) szerint a globális vasúti ipar éves volumene 160 milliárd euró. 2014 - 2020 közötti időszakban, mint egy 950 millió eurót fordítanak vasúti kutatás-fejlesztésre az EU-ban. [6]

A vasúti ágazat jelentős innovációs potenciállal bír. Amire jó példák a következő fejlesztések: automata akadály elörejelzés vasúti jármüvek számára, hatékonyabb vontatási energiaellátás, fedélzeti energiatároló rendszerek, regeneratív fékezés, infrastruktúra hasznos élettartamát pozitívan befolyásoló csendes forgóvázak, komplex monitoring-rendszerek [7] [8], mühold alapú helymeghatározó rendszerek, hibrid dízelelektromos meghajtások, könnyüfémek, környezetbarát jármüipari hegesztéstechnológia [9], RFID technológia alkalmazása [10], SMART vasúti technológiák [11].

Magyarországon a közelmúlt kutatásfejlesztési eredményei közé sorolhatók a vasúti jármű ipari fejlesztések: új nemzetközi forgalomban is használható InterCity jármüvek, fékmechanikai és fékvezérlési komponensek fejlesztése. További eredmények születtek fénysorompó LED-optika vagy éppen a felépítmény vizsgáló mérőkocsi létrehozása kapcsán is. Ezek a kutatás-fejlesztések felélesztették a már szinte elfeledett vasúti fejlesztéseket.

Sajnos a fejlesztések elszórt egyedi esetek és nem strukturált fejlesztési stratégia részei. 2013-ban a Nemzeti Közlekedési Stratégia, Országos Vasútfejlesztési Koncepció vitaanyagában az oktatás, kutatásfejlesztés, innováció kapcsán egy kívülröl irányított, követő jellegü $\mathrm{K}+\mathrm{F}+\mathrm{I}$ tevékenységről számoltak be, ami a magyar önálló kutatási bázis megszünését jelezte. [12] 


\section{Következtetések}

A hosszútávú fejlesztési stratégia hiánya a vasúti ágazat versenyképeségét negatívan befolyásolja Magyarországon. Ugyanakkor pedig európai szinten a vasúti iparban jelentős fejlesztések mennek végbe. Az Ipar 4.0 hatásai a vasúti szektorban is észlelhetők.

Magyarországon a vasúti ágazatban további lehetőségek rejlenek, amelyet szükséges volna feltárni és az innovációs potenciált kihasználva növelhetővé válna a vasúti ágazat gazdaságélénkítő szerepe.

Mi tehát a digitalizáció a vasúti ágazatot érintően és hogyan kapcsolódhat az európai kutatás-fejlesztésekhez?

A vasút tekintetében a digitalizáció a digitális technológiák széleskörü alkalmazását jelenti. Ami ma még hazánkban nem minden vasúti szakterületen nyilvánvaló. De a digitális technológiák térnyerése egyre bizonyosabb erre jó példa a német vasút is.

A német vasút digitális vasúttá való válásának és az ezzel kapcsolatos kutatásfejlesztései stratégiának az elmei között szerepel az európai vonat befolyásoló rendszer tovább fejlesztése és minél jelentősebb elterjesztése, még több elektronikus biztosítóberendezés telepítése, az energiahatékonyság növelése, a vasúti biztonság növelése, illetve a karbantartás intelligensététele is.

Az Európai Uniós Hálózat- és Információbiztonsági Ügynökség (ENISA) szerint a kritikus infrastruktúrák - a vasút is ilyen - és az IoT kapcsolatából jöhet létre a smart infrastruktúra. A smart infrastruktúrák része a közösségi közlekedés így a vasúti infrastruktúra is. [13] A közlekedési rendszer eleme egy nagyobb egésznek ez pedig a okos város (smart city), ami szintién az IKT technológiák segítségével javítja a városlakók életminőségét. [14]

A kiber és fizikai világ kapcsolatával új kihívások elé néz társadalmunk. Ilyen terület például a felhőtechnológiák alkalmazásából fakadó kérdések. A digitális technológiák terjedésével egyre hozzáférhetőbb erőforrásfelhasználás szempontjából hatékony megoldások estében szükséges a vasúti szakterületen is a kibertér biztonságos alkalmazása. [15] A jövőben a különféle infrastrukturális hálózattokat biztonságos üzemeltetése és védelme nem csak a fizikai világ kapcsán lesz fontos [16].

Összefoglalva a vasúti kutatásfejlesztésre Magyarországon is szükség van, mert a hazai vasút versenyképessége függ a hazai innovációktól. A vasúti ágazat hosszútávú fejlődéséhez elengedhetetlen elem a digitális technológiák alkalmazása. Létre kell tehát hozni a magyar Digitális Vasúti Stratégiát, melynek eleme lehet számos már említett dolog.

\section{Köszönetnyilvánítás}

Az előadás/publikáció alapjául szolgáló kutatás a „Intelligens vasúti informatikai és biztonsági rendszerek fejlesztése" címü projekt keretében zajlott. Amely kutatás a Nemzeti Tehetség Program, a Nemzet Fiatal Tehetségeiért Ösztöndíj (Pályázati azonosító: NTP-NFTÖ-16-0582) által biztosított forrás felhasználásával és az Emberi Erőforrás Támogatáskezelő és az Emberi Erőforrások Minisztériuma támogatásával valósul meg.

\section{Szakirodalmi hivatkozások}

[1] Holicza, P., Tokody, D.: Field of Challenges: A Critical Analysis of the Hungarian SME Sector within the European Economy. Hadmérnök, 9(3) 2016, pp. 110-120.

[2] The Boston Consulting Group: The 2015 European Railway Performance Index Econostrum www.econostrum.info/attachment/573787/

[3] Tokodi D., Papp J., Schuster Gy.: The challenges of the intelligent railway network implementation: Initial thoughts from Hungary. Proceedings of the 3rd international conference and workshop Mechatronics in Practice and Education - MECHEDU 2015. Szabadka, Szerbia, 2015. pp. 179-185. ISBN:978-86-918815-0-4

[4] Rajnai Z., Nyikes Z.: A Big Data alkalmazása a nemzeti digitális közmüben. 
Szakmai Szemle: A Katonai Nemzetbiztonsági Szolgálat TudományosSzakmai Folyóirata, ISSN 1785 - 1181, 2015:(4) pp. 103-118.

[5] Nemzeti Infokommunikációs Stratégia $2014-2020$

http://digitalismagyarorszag.kormany.hu/do wnload/e/35/e0000/Nemzeti\%20Infokommu nik\%C3\%A1 ci $\%$ C3\%B3s $\% 20$ Strat $\%$ C3\%A 9gia.pdf

[6] http://www.unife.org/component/attachments $/$ ?task $=$ download\&id $=731$

[7] Bitay E., Bagyinszki Gy.: Robotok és a sajtoló hegesztések fejlesztései. A XXI. Fiatal Müszakiak Tudományos Ülésszaka előadásai. ISSN 2393-1280, EME, MTK 5. szám, Kolozsvár, 2016. pp. 101-104.

[8] Kovács T., Nyikes Z., Tokody D.: Komplex monitoring-rendszer használata vasúti felépitmény vizsgálatában az Ipar 4.0-hoz. XVII. Müszaki Tudományos Ülésszak előadásai. ISSN 2393-1280, EME, MTK 6. szám, Kolozsvár, 2017.

[9] F. Flammini, C. Pragliola, G. Smarra: Railway infrastructure monitoring by drones, 2016 International Conference on Electrical Systems for Aircraft, Railway, Ship Propulsion and Road Vehicles \& International Transportation Electrification Conference (ESARS-ITEC), Toulouse, France, 2016, pp. 1-6. 10.1109/ESARSITEC.2016.7841398

[10] Papp J., Tokodi D., Schuster Gy.: Díjnyertes intelligens vasútirányitási rendszer: Intelligens biztonságtechnikai kutatások az Óbudai Egyetemen. Innorail Magazin I:(4) pp. 46-49. 2014.

[11] Tokody D., Schuster Gy., Papp J.: Study of how to implement an intelligent railway system in Hungary, 2015 IEEE 13th International Symposium on Intelligent Systems and Informatics (SISY), Subotica, 2015, pp. 199204. doi: 10.1109/SISY.2015.7325379

[12] Nemzeti Közlekedési Stratégia (2013. 10.) http://www.kkk.gov.hu/remos downloads/N KS Strategiai dokumentum. 26 .pdf.

[13] European Union Agency for Network and Information Security: IoT and Smart Infrastructures

https://www.enisa.europa.eu/topics/iot-andsmart-infrastructures

[14] Tokody D., Schuster Gy.: Driving Forces Behind Smart City Implementations - The Next Smart Revolution. Journal of Emerging Research and Solutions in ICT, Vol.1, No.2, 1-16, 2016. doi:10.20544/ERSICT.02.16.P01

[15] Albini A.: IT felhök biztonsága. Proceedings of 8th International Engineering Symposium at Bánki. Budapest, Magyarország, 2016. Budapest: Óbudai Egyetem, 2016. Paper 07. 6 p. ISBN:978615-5460-95-1

[16] Werner Á. G.: Fuzzy logic adapted controller system for biometrical identification in highly-secured critical infrastructures, IEEE 10th Jubilee International Symposium on Applied Computational Intelligence and Informatics, Timisoara, 2015, pp. 335-340. doi: 10.1109/SACI.2015.7208224 